University of Nebraska - Lincoln

DigitalCommons@University of Nebraska - Lincoln

2000

Nutrients in Groundwaters of the Conterminous United States, 1992-1995

Bernard Nolan

U.S. Geological Survey

Jeffrey Stoner

U.S. Geological Survey

Follow this and additional works at: https://digitalcommons.unl.edu/usgsstaffpub

Part of the Earth Sciences Commons

Nolan, Bernard and Stoner, Jeffrey, "Nutrients in Groundwaters of the Conterminous United States, 1992-1995" (2000). USGS Staff -- Published Research. 59.

https://digitalcommons.unl.edu/usgsstaffpub/59

This Article is brought to you for free and open access by the US Geological Survey at DigitalCommons@University of Nebraska - Lincoln. It has been accepted for inclusion in USGS Staff -- Published Research by an authorized administrator of DigitalCommons@University of Nebraska - Lincoln. 


\section{Nutrients in Groundwaters of the Conterminous United States, 1992-1995}

\author{
BERNARD T. NOLAN*, + AND \\ JEFFREY D. STONER \\ U.S. Geological Survey, 413 National Center, \\ Reston, Virginia 20192, and U.S. Geological Survey, \\ Denver Federal Center, Mail Stop 415, Box 25046, \\ Lakewood, Colorado 80225
}

Results of a national water quality assessment indicate that nitrate is detected in $71 \%$ of groundwater samples, more than 13 times as often as ammonia, nitrite, organic nitrogen, and orthophosphate, based on a common detection threshold of $0.2 \mathrm{mg} / \mathrm{L}$. Shallow groundwater (typically 5 $\mathrm{m}$ deep or less) beneath agricultural land has the highest median nitrate concentration $(3.4 \mathrm{mg} / \mathrm{L})$, followed by shallow groundwater beneath urban land $(1.6 \mathrm{mg} / \mathrm{L})$ and deeper groundwater in major aquifers $(0.48 \mathrm{mg} / \mathrm{L})$. Nitrate exceeds the maximum contaminant level, $10 \mathrm{mg} / \mathrm{L}$ as nitrogen, in more than $15 \%$ of groundwater samples from 4 of 33 major aquifers commonly used as a source of drinking water. Nitrate concentration in groundwater is variable and depends on interactions among several factors, including nitrogen loading, soil type, aquifer permeability, recharge rate, and climate. For a given nitrogen loading, factors that generally increase nitrate concentration in groundwater include well-drained soils, fractured bedrock, and irrigation. Factors that mitigate nitrate contamination of groundwater include poorly drained soils, greater depth to groundwater, artificial drainage systems, intervening layers of unfractured bedrock, a low rate of groundwater recharge, and anaerobic conditions in aquifers.

\section{Introduction}

Increased use of nitrogen and phosphorus fertilizers in the last half century has led to increased potential for contamination of groundwater by nutrients. Nitrogen fertilizer use in theUnited States increased 20-fold, and use of phosphorus fertilizer more than tripled during 1945-1993, according to estimates compiled by Puckett (1). Inorganic fertilizer contributed about 10 million $\mathrm{t}(\mathrm{t}=$ metric ton) of nitrogen and about 2 million t of phosphorus nationwidein 1993, and animal manure contributed about 6 million t of nitrogen and about 2 million t of phosphorus. Additionally, about 3 million $t$ of nitrogen/year are deposited nationwide from atmospheric sources (1). Other nonagricultural sources of nitrogen, such as septic systems and leaking sewers, contributelesser amounts regionally and nationally but can affect local groundwater quality.

Contamination of groundwater by nitrate-the most common nutrient in groundwater-is a health concern

\footnotetext{
* Corresponding author e-mail: btnolan@usgs.gov; telephone: (703)648-4000; fax: (703)648-6693.

+ U.S. Geological Survey, Reston, VA.

₹ U.S. Geological Survey, Denver, CO.
}

because groundwater sources provide drinking water for more than half the population of the United States (2). Ingestion of nitrate in drinking water by infants can cause low oxygen levels in the blood, a potentially fatal condition (3). For this reason, theU.S. Environmental Protection Agency (U.S. EPA) has established a maximum contaminant level (MCL) of $10 \mathrm{mg} / \mathrm{L}$ nitrateas nitrogen (4). Other adverse health effects from nitrate havebeen implicated in recent literature. A case study in Indiana indicated that nitrateconcentrations of $19-29 \mathrm{mg} / \mathrm{L}$ in rural, domestic wells might have caused eight spontaneous abortions among four women during 1991-1994 (5). Nitrate concentrations of $4 \mathrm{mg} / \mathrm{L}$ or more in water from community wells in Nebraska have been associated with increased risk of non-Hodgkin's lymphoma (6). Nitrate concentration in groundwater unaffected by human activities generally is less than $2 \mathrm{mg} / \mathrm{L}$ (7).

Groundwater quality criteria have not been established for phosphorus, but phosphorus in groundwater represents a potential source of this nutrient in streams that derive most of their flow from groundwater. Because of eutrophication concerns, the U.S. EPA has established a goal that total phosphate not exceed $0.05 \mathrm{mg} / \mathrm{L}$ in a stream where it enters a lake or reservoir and that total phosphorus in streams that do not discharge directly to lakes or reservoirs should not exceed $0.1 \mathrm{mg} / \mathrm{L}$ (8).

The U.S. Geological Survey's National Water-Quality Assessment (NAWQA) Program addresses water quality concerns by sampling water resources in more than 50 prominent hydrologic systems (called study units) of the Nation. The Program employs consistent methods with respect to laboratory analytical techniques and sensitivity, and-regarding groundwater-well selection, construction criteria, and sampling depth. Three types of groundwater studies conducted by NAWQA are discussed in this paper: (i) agricultural land-use studies, which sample shallow groundwater (typically about $5 \mathrm{~m}$ deep or less) beneath agricultural land; (ii) urban land-use studies, which sample shallow groundwater beneath urban land; and (iii) major aquifer surveys, which sample groundwater irrespective of overlying land use and that usually is deeper than groundwater associated with land-usestudies. Major aquifers usually are larger in areal extent than land-use studies. Results from these studies are aggregated to yield assessments of groundwater quality at regional and national scales.

This paper describes the occurrence and the distribution of nutrients in groundwater beneath agricultural and urban lands and in major aquifers, based on studies conducted during 1992-1995 by the first 20 NAWQA study units, which began study activities in 1991 (Table 1). Related objectives areasfollows: (i) to summarizenutrient concentrations and detection frequencies in major aquifers and in shallow groundwater beneath agricultural and urban lands; and (ii) to relate nitrate concentration in shallow groundwater to natural and human factors.

\section{Methods}

The NAWQA Program is designed to enhance understanding of natural and human factors that affect water quality. Landuse studies evaluate the quality of recently recharged groundwater (generally less than 10 years old) for regionally extensive combinations of land-use and hydrogeologic conditions (9). Land-use studies represent the intersection of a targeted land use and an aquifer of interest. Wells in land-usestudiestypically areinstalled by NAWQA, and public supply wells are avoided because of uncertainties in the location of the recharge area. Someland-use studies sample 


\begin{tabular}{|c|c|}
\hline $\begin{array}{l}\text { study unit } \\
\text { abbrev }\end{array}$ & study unit name \\
\hline ACFB & Apalachicola-Chattahoochee-Flint River Basin \\
\hline ALBE & Albemarle-Pamlico Drainage \\
\hline ССРТ & Central Columbia Plateau \\
\hline CNBR & Central Nebraska Basins \\
\hline CONN & Connecticut, Housatonic, and Thames River Basins \\
\hline GAFL & Georgia-Florida Coastal Plain \\
\hline HDSN & Hudson River Basin \\
\hline LSUS & Lower Susquehanna River Basin \\
\hline NVBR & Nevada Basin and Range \\
\hline OZRK & Ozark Plateaus \\
\hline РOTO & Potomac River Basin \\
\hline REDN & Red River of the North Basin \\
\hline RIOG & Rio Grande Valley \\
\hline SANJ & San J oaquin-Tulare Basins \\
\hline SPLT & South Platte River Basin \\
\hline TRIN & Trinity River Basin \\
\hline USNK & Upper Snake River Basin \\
\hline WHIT & White River Basin \\
\hline WILL & Willamette Basin \\
\hline WMIC & Western Lake Michigan Drainages \\
\hline
\end{tabular}

shallow domestic wells. The shallow, recently recharged groundwater beneath a given land use might or might not be used for drinking. In contrast, groundwater in major aquifers is commonly deeper than that sampled in land-use studies. The deeper groundwater in major aquiferscommonly used for drinking-is evaluated irrespective of overlying land use because deeper groundwater typically is older than shallow groundwater and is less likely to show effects from recent land use.

The land-use and major aquifer studies adhere to welldesign and construction criteria to ensure that water quality samples represent the targeted aquifer $(10,11)$. Well locations are randomly selected within study areas to facilitate statistical analysis of groundwater quality (12). The data set used for this paper comprises 2130 wells sampled by the first 20 NAWQA study units, which began study activities in 1991 (Figure 1). The 36 agricultural land-use studies comprise 926 wells, the 13 urban land-use studies comprise 309 wells, and 895 wells are completed in 33 major aquifers. Springs and agricultural drains were excluded from consideration here because of uncertainties in the source of water and contributing land-use area. All wells were sampled according to procedures described by Koterba and others (13). Nutrient analyses consisted of those for dissolved concentrations of ammonia, nitrite, ammonia plus organic nitrogen, nitrite plus nitrate, and orthophosphate. Concentrations of nitrogen species are based on elemental nitrogen (e.g., $\mathrm{NO}_{2}^{-}$as $\mathrm{N}$ ), and orthophosphate concentration is based on elemental phosphorus. Nutrient samples were analyzed by the USGS National Water Quality Laboratory using procedures described in Fishman (14) and in Patton and Truitt (15). To preclude undue influence on results by wells that were sampled several times, only the most recent sample per well was used in statistical analyses.

Adjusted detection frequencies were calculated for each nutrient using a common detection threshold of $0.2 \mathrm{mg} / \mathrm{L}$. Use of a common detection threshold allows unbiased comparisonsamong differentcompounds (16). Although raw detection frequencies maximize the ability to detect individual compounds, they cannot be used to compare occurrences of different nutrients becausea compound's frequency of detection is inversely related to its analytical reporting limit (17). Method detection limits for nutrients range from 0.01 to $0.2 \mathrm{mg} / \mathrm{L}$ (Table 2). After an adjusted detection frequency for each sampling network (i.e., each land-use study or major aquifer) was calculated using data from individual wells, median detection frequency was cal culated for individual nutrients using theadjusted, network detection frequencies as input. To enhance comparability of detections among individual nutrients, the concentration of "organic nitrogen" was calculated as the difference between the concentrations of ammonia plus organic nitrogen and ammonia in a sample, and "nitrate" was calculated as the difference between nitrite plus nitrate and nitrite concentrations.

Nutrient concentrations were statistically analyzed first by determining median concentrations in groundwater for each land-use study and major aquifer as described below and then by using these medians as input to additional analyses. Medianswere used as a measure of central tendency because they are resistant to the effects of outliers typical of skewed data sets.

First, median nutrient concentrations within sampling networks were calculated using individual wells in a network (i.e., agricultural land-use study, urban land-use study, or major aquifer) to negatesampling biasintroduced by network size. Some networks include more than 100 wells, but most have 30 wells or less. Networks with fewer than 10 wells were not used in this study. Censored values were set to half the detection limit before calculating network medians. Group medians representing each type of groundwater study (agricultural land use, urban land use, major aquifer) then were calculated using the appropriate network medians as input. For example, the median nitrite plus nitrate concentration of agricultural land-use studies was calculated from network medians associated with each agricultural land-use study.

For mapping purposes, lower (25th percentile) and upper quartiles (75th percentile) of land-usenetwork medians were calculated to rank agricultural and urban land-use studies as highest, middle, or lowest with respect to median nitrate concentration. A land-use network in the highest category has median nitrate concentration in groundwater greater than the 75th percentile of $5 \mathrm{mg} / \mathrm{L}$, and a land-use network in the lowest category has median nitrate concentration less than the 25th percentile of $0.5 \mathrm{mg} / \mathrm{L}$. The remaining landuse networks were ranked in the middle category. Exceedances of the nitrate MCL ( $10 \mathrm{mg} / \mathrm{L}$ as $\mathrm{N}$ ) were determined using (i) individual wells in major aquifer networks for mapping purposes and (ii) individual wells grouped by type of groundwater study, by calculating the percent of wells with a nitrate sample that exceeds the MCL.

TheKruskal-Wallistest and analysis of variance(ANOVA) on ranked data were performed to test for differences in data grouped by type of groundwater study (agricultural land use, urban land use, major aquifer), again using network medians as input. When the Kruskal-Wallis test, a nonparametric test equivalent in purpose to ANOVA, agrees with ANOVA on the ranks, it confirms that no assumptions required by the parametric test are violated. Where differences between data groups werefound by ANOVA on theranks, Tukey's multiplecomparison test was performed on the ranks to determine which groups were different. Test results were evaluated at the 0.05 level of significance.

Nitrogen loading data from atmospheric deposition, animal manure, and commercial fertilizer were compiled in geographic information systems (GISs) to evaluate effects on nitrate concentration in shallow groundwater beneath agricultural land use. Average annual nitrogen loading from commercial fertilizer was compiled from national databases of county fertilizer sales (Jerald J. Fletcher, West Virginia University, unpublished data, 1998) and averaged for 19911993 (Kerie J. Hitt, USGS, unpublished data, 1998) using methods described by Battaglin and Goolsby (18). Average 


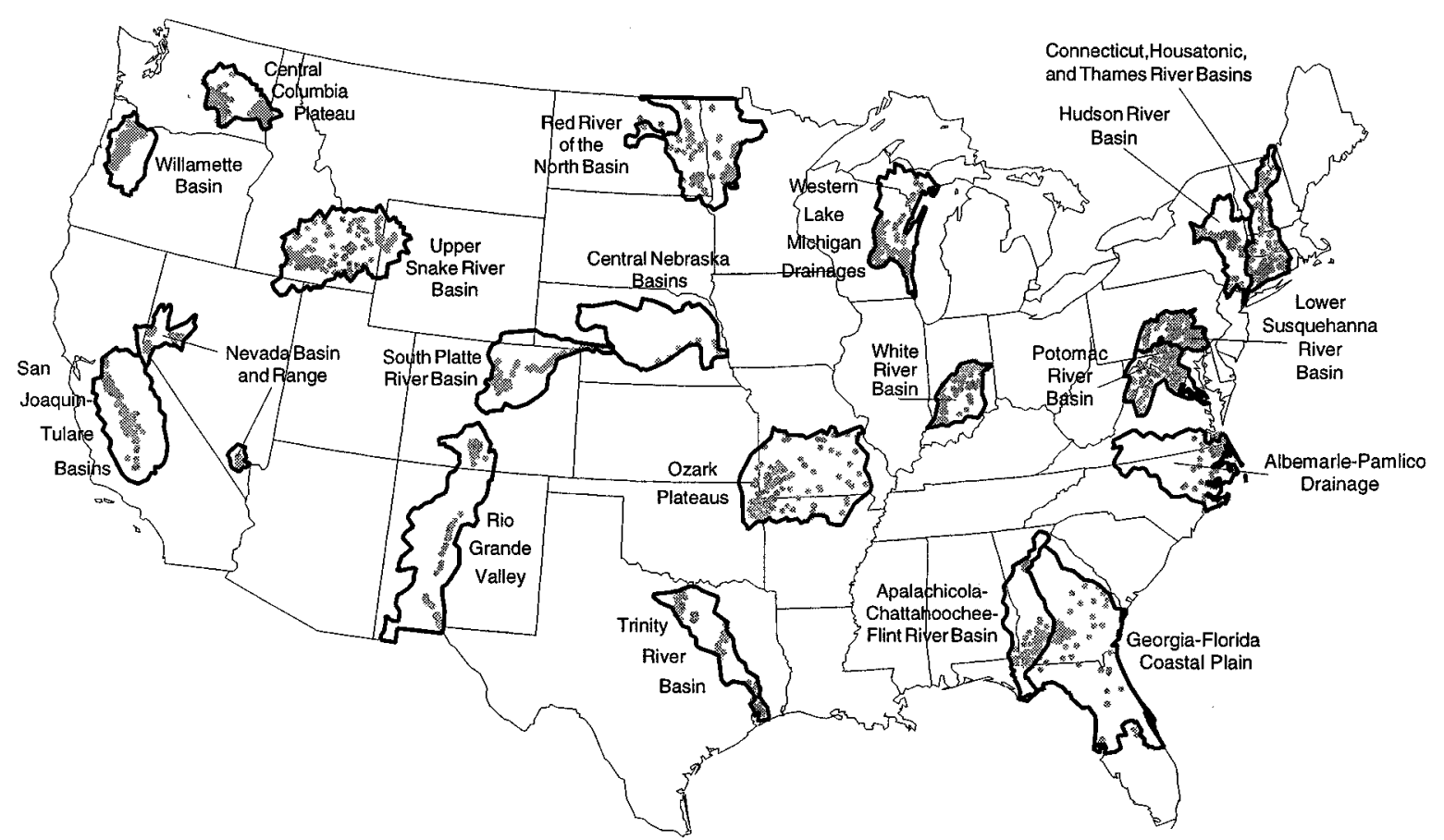

FIGURE 1. Locations of wells sampled as part of NAWQA land-use studies and major aquifer surveys conducted during $1992-1995$.

TABLE 2. Median Concentrations of Nutrients in Samples from NAWQA Groundwater Studies and Median Depth to Groundwater and to Sampled Zone within Aquifer

w ater quality variable or w ell parameter

ammonia as $\mathrm{N}(\mathrm{mg} / \mathrm{L})$

nitrite as $\mathrm{N}$ (mg/L)

ammonia plus organic nitrogen as $\mathrm{N}(\mathrm{mg} / \mathrm{L})$

nitrite plus nitrate as $\mathrm{N}(\mathrm{mg} / \mathrm{L})$

orthophosphate as $\mathrm{P}(\mathrm{mg} / \mathrm{L})$

depth to groundwater $(\mathrm{m})$

depth to top of open interval below water level $(m)$

\section{$M D L,{ }^{a} \mathrm{mg} / \mathrm{L}$}

$0.01,0.015^{b}$

0.01

0.20

0.05

0.01

agric. land use
0.02
$<0.01$
$<0.2$
3.4
0.01
5.1
3.5

3.5

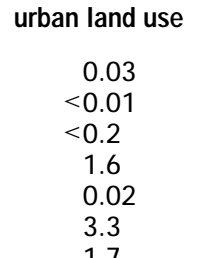

1.7
major aquifer
0.02
$<0.01$
$<0.2$
0.48
0.01
6.8

6.8

a Method detection limit. ${ }^{b}$ Ammonia method has two detection limits.

annual loading of inorganic nitrogen by atmospheric deposition was estimated for the same period (Barbara C. Ruddy and David M. Wolock, USGS, unpublished data, 1998) using data from the National Atmospheric Deposition Program/ National Trends Network (19). Nitrogen loading from animal manure was compiled at the county level by Puckett and others (20) from 1992 Census of Agriculture animal population data (21), based on per animal nitrogen-production rates (22). Corrections for nitrogen losses by volatilization of ammonia during storage and handling of manure were not applied because volatilized nitrogen can be redeposited locally, as shown in Puckett and others (23).

Nitrogen loading rates are seldom uniform within a county and depend in part on variations in land use. In this study, county-level fertilizer and manure loadings were apportioned in a GIS by land use to reflect variations in loadings within counties to achieve greater spatial accuracy than if loadings had been assumed uniform at the county level. Nitrogen fertilizer loading data were apportioned uniformly to agricultural and urban lands with the following Anderson Level II designations: cropland/pasture; orchards/vineyards; residential; new residential; commercial/ services; transportation, communications, and utilities; mixed urban or builtup; and other urban or builtup land (24) (Kerie J. Hitt, USGS, unpublished data, 1998). The Anderson land-use data were updated with 1990 Census population data to indicate recent conversion of agricultural land to new residential land (25). Manure loading was apportioned to cropland/ pasture only.
Nitrogen loading from atmospheric deposition was assumed independent of Anderson land use compiled at the county level.

Weighted averages of nitrogen loading from fertilizer and manure were calculated for $500-\mathrm{m}$ radius circular areas around each well, based on the percentage of Anderson Level II agricultural and urban land around each well. (Nitrogen loading from atmospheric deposition was assumed independent of land use within $500 \mathrm{~m}$ of a sampled well.) The 500 - $\mathrm{m}$ value was used because (i) it yielded the strongest correlations between groundwater nitrate and agricultural and urban land uses, based on sensitivity analysis of circular areas with radii from 250 to $2000 \mathrm{~m}$ (Bernard T. Nolan, USGS, unpublished data, 1998) and (ii) it is a reasonable area of influence for sampling depths below water level used in this study.

Mean nitrogen loadings within NAWQA study units were calculated from data compiled within 500 m of each well in agricultural land-use studies to evaluate differences in nitrogen sources (fertilizer, manure, and atmospheric deposition) within and between study units. Agricultural landuse studies were used as a basis for comparison because they received nitrogen from all three sources in the land-use apportioning exercise described above.

Soil drainage characteristic was determined from soil hydrologic group data in theState Soil Geographic (STATSGO) database (26) and was compiled in 1:250 000 scale GIS maps (Barbara C. Ruddy, USGS, unpublished data, 1998). The soil 
hydrologic group variable has four major categories ranging generally from well-drained soils (groups A and B) to poorly drained soils (groups $C$ and D). The categorical variable was converted to a continuous variable by using a GIS to compile the percent area of each soil hydrologic group within a given agricultural land-use study. Wells then were assigned the percent area of well-drained soils (hydrologic groups A and B) associated with the agricultural land-use study in which they reside.

\section{Results and Discussion}

Occurrence of Nutrientsin Groundwater. Adjusted detection frequencies were calculated for each land-use study and major aquifer based on a common detection threshold of 0.2 $\mathrm{mg} / \mathrm{L}$, and from these network values median detection frequencies were calculated for each nutrient. Nitrate was detected more than 13 times as often as any other nutrient. Nitrate was detected in $71 \%$ of groundwater samples, followed by organic nitrogen (5.3\%) and ammonia (5.1\%). Nitrite and orthophosphate were not detected in any samples in concentrations at or exceeding the common detection threshold of $0.2 \mathrm{mg} / \mathrm{L}$.

Median concentrations of nutrients were calculated for each type of groundwater study (agricultural land use, urban land use, major aquifer) based on sampling network medians. Nitrite plus nitrate has the highest range of median concentrations of any nutrient $(0.48-3.4 \mathrm{mg} / \mathrm{L}$ ) (Table 2$)$ and is the predominant nutrient found in shallow groundwater underlying agricultural and urban lands and in major aquifers. Median concentrations of ammonia $(0.02-0.03 \mathrm{mg} /$ $\mathrm{L})$, ammonia plus organic nitrogen $(<0.2 \mathrm{mg} / \mathrm{L})$, nitrite $(<0.01$ $\mathrm{mg} / \mathrm{L})$, and orthophosphate $(0.01-0.02 \mathrm{mg} / \mathrm{L})$ are comparatively low and indicate chemical instability, smaller loadings, and/ or limited mobility of these nutrients in groundwater.

Biogeochemical transformationsinfluencetheoccurrence and distribution of nitrogen species in groundwater. Ammonia and organic forms of nitrogen are readily transformed in groundwater. Organic forms of nitrogen, such as urea, are mineralized to ammonia under both anaerobic and aerobic conditions when organic matter decomposes (27). Ammonia is soluble in water but is converted to nitrogen gas in anaerobic systems and to ammonium hydroxide in aerobic systems. Most of the ammonium hydroxide is ionized to ammonium and hydroxyl ions. Under aerobic conditions, ammonium ion is converted to nitrite and nitrate by nitrification, a microbially assisted process. Whereas nitrite is unstable under aerobic conditions, nitrate can persist in groundwater for decades.

Phosphorus solubility and mobility in water are limited, which might explain why median orthophosphate concentration is low in the groundwater data set. Additionally, estimated nitrogen loadings from animal manure and inorganic fertilizers are 3-5 times that of estimated phosphorus loadings (1). Phosphorus, however, is present in domestic and industrial sewage effluents (28), which might explain whymedian orthophosphate concentration in urban land-use studies $(0.02 \mathrm{mg} / \mathrm{L})$ is higher than in agricultural land-usestudiesand in major aquifers(Table2). For example, leakage of effluent from municipal sewer systems can contaminate groundwater in residential areas (29). Additionally, sodium phosphate was a component of household cleaning detergents in the 1950s and 1960s and might have reached some aquifers through septic drain fields in residential areas. Phosphate is the most significant form of phosphorus in natural water, and orthophosphateis the most thermodynamically stable form of phosphate (28).

From this point on, nitrite plus nitrate is referred to in this paper as "nitrate". Nitrite concentration commonly is less than the method detection limit of $0.01 \mathrm{mg} / \mathrm{L}$ in groundwaters sampled in this study, resulting in negligible 2(a) Nitrite-plus-nitrate

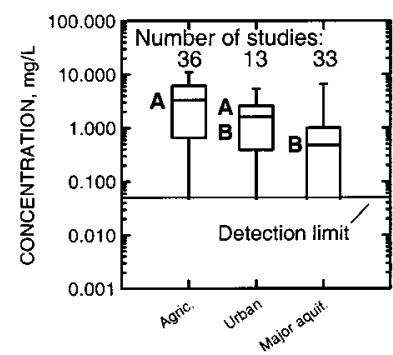

2(c) Orthophosphate

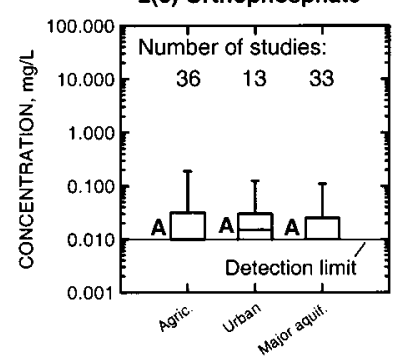

FIGURE 2. Distributions of (a) nitrite plus nitrate, (b) ammonia, and (c) orthophosphate concentrations in groundwater samples from land-use studies and major aquifers.

contribution to nitrite plus nitrate concentration. Additionally, the corresponding U.S. EPA MCL for nitrite plus nitrate is $10 \mathrm{mg} / \mathrm{L}$ as $\mathrm{N}$, the same as for nitrate alone.

Shallow groundwater beneath agricultural land has the highest median concentration of nitratein ground water (3.4 $\mathrm{mg} / \mathrm{L}$ ), which is greater than in shallow ground water beneath urban land $(1.6 \mathrm{mg} / \mathrm{L})$ and in samples from major aquifers (0.48 $\mathrm{mg} / \mathrm{L}$ ) (Table 2 and Figure 2a). Tukey's multiple comparison test on the ranks indicates that median nitrate concentration in major aquifers is significantly different ( $p$ $=0.0002$ ) from that in shallow groundwater beneath agricultural land. Differences in groundwater nitrate concentration beneath agricultural land and urban land $(p=0.34)$, and beneath urban land and in major aquifers $(p=0.20)$, are not statistically significant at the 0.05 level. Box plots labeled with thesameletter in Figure2a (e.g., " $A$ " for both agricultural and urban lands) indicate that differences in nitrate concentration are not statistically significant. The median and hinges shown in the box plots in Figure 2 divide the sample values into four groups of equal size. Themedian divides the ordered values in half, and the hinges subdivide the two halves in half again. The whiskers indicate values that fall within 1.5 times the interquartile range, which is the difference between the upper and the lower hinges. Percentilesabovethe method detection limit are known exactly, whereas those below the detection limit are not. Therefore, the boxplots aretruncated below themethod detection limits.

Box plots also were prepared for ammonia (Figure 2b), which had median concentrations greater than the detection limit for each type of groundwater study (agricultural land use, urban land use, and major aquifer) (Table 2), and for orthophosphate (Figure 2c), the most common form of phosphorus in natural water. ANOVA on the ranks indicated that ammonia and orthophosphate concentrations are not significantly different among groundwater samples from agricultural and urban land-use studies and major aquifers. ANOVA yielded $p$ values of 0.24 and 0.96 for ammonia and orthophosphate, respectively. Median groundwater concentrations of these nutrients are equal to or slightly greater than associated method detection limits in land-use studies and in major aquifers (Table 2). The remainder of this paper focuses on nitrate because it is the predominant nutrient found in groundwaters sampled in this study. 


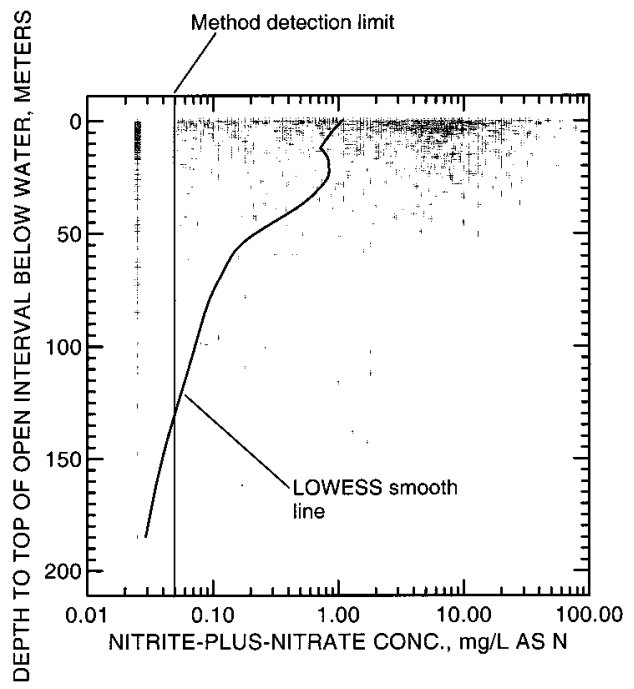

FIGURE 3. Relation betw een sampling depth within the aquifer and nitrate concentration in groundw ater for w ells in land-use studies and major aquifers.

Nitrate Concentration in Groundwater. Median nitrate concentration is highest in shallow groundwater beneath agricultural land. Compared with most major aquifer surveys, land-use studies sample shallow, recently recharged groundwater and are more likely to show effects of nitrogen inputs to the land surface. Median nitrogen loading within $500 \mathrm{~m}$ of sampled wells was as high as $210 \mathrm{~kg} / \mathrm{ha}$ in agricultural land-usestudy areas. In prior research, nitrate concentrations in shallow groundwater were elevated in areas with high nitrogen input from inorganic fertilizers, animal manure, and atmospheric deposition (30), the same sources used in the current study.

The low median concentration of nitrate in major aquifers (Figure 2a) indicates sampling of deeper groundwater. The depth to the top of the open interval (well screen or open borehole) below water level was calculated in this study to represent "sampling depth" within aquifers. Deeper sampling depths generally correspond to older groundwater and anaerobic conditions. In an unconfined aquifer, sampling depth represents the distance from the water table surface to the top of the open interval; but in a confined aquifer, sampling depth represents the distance from the potentiometric surface to the top of the open interval, which can include unsaturated as well as saturated materials. Water table and potentiometric surface height can differ in a given area, especially in hilltop and deep valley topographic settings. In settings typical of NAWQA wells, however, water table and potentiometric surface height are about the same, and the depth below water to the top of the open interval is used to represent sampling depth within the saturated zone of aquifers.

The LOWESS (locally weighted scatterplot smooth) line in Figure 3 indicates that nitrate concentration in groundwater generally decreases as sampling depth within aquifers increases. The LOWESS smooth is a moving, local average of the valuesassociated with individual wellsshown in Figure 3. Median sampling depth is $6.8 \mathrm{~m}$ in major aquifers as compared with 1.7-3.5 $\mathrm{m}$ for agricultural and urban landuse studies (Table 2). Tukey's multiple comparison test on the ranks indicates that sampling depth in major aquifers is significantly different from that in surficial aquifers beneath agricultural $(p=0.03)$ and urban $(p=0.01)$ lands. Differences in sampling depth for the two types of land uses $(p=0.52)$, however, are not statistically significant-as expected because both types of land-usestudies are designed to sample shallow, recently recharged groundwater.
Whereas NAWQA land-use studies sample recently recharged groundwater (that might or might not be used for drinking) beneath specific land uses, major aquifer studies usually sample deeper groundwater that commonly is used for drinking. Nitrate contamination of deeper groundwater is less likely to occur for three reasons. First, in areas with greater depth to groundwater, contaminants introduced at the land surface must travel farther to reach groundwater. Median depth to groundwater is $6.8 \mathrm{~m}$ in major aquifers, but only 3.3-5.1 $\mathrm{m}$ in urban and agricultural land-use studies (Table 2). Second, nitrate is less stable under anaerobic conditions typical of deeper sampling depths below water and can betransformed to nitrogen gas or reduced nitrogen species, such as ammonium. Third, deeper groundwater commonly is older and less likely to show effectsfrom recent land use. For example, groundwater older than 50 years is unlikely to show effects from increased fertilizer loading that occurred over the last half-century.

The nitrate MCL is exceeded more often in shallow groundwater beneath agricultural land than in shallow groundwater beneath urban land and in groundwater in major aquifers. Samples from $19 \%$ of wells in agricultural lands exceed the nitrate $\mathrm{MCL}$ of $10 \mathrm{mg} / \mathrm{L}$ as N. In contrast, 3.9 and $5.3 \%$ of samples from urban lands and from major aquifers, respectively, exceed the nitrate MCL. The exceedance percentage for major aquifers seems high when compared with that for urban lands, but notall major aquifers are deep, and most wells with exceedances are completed in a few aquifers that are highly contaminated by nitrate. For example, median sampling depth $(2.7 \mathrm{~m})$ and depth to water $(1.7 \mathrm{~m})$ in sampled wells in the Platte River alluvial aquifer in central Nebraska are significantly less than the typical values shown for major aquifers in Table 2. The Platte River alluvial aquifer is overlain by extensive areas of irrigated and fertilized corn, and $36 \%$ of samples from this major aquifer exceed the nitrate $\mathrm{MCL}$ of $10 \mathrm{mg} / \mathrm{L}$ as $\mathrm{N}$.

National Patterns of Nitrate Concentration in Groundwater. Median nitrate concentration was mapped at the national scale to show spatial patterns of nitrate concentration in shallow groundwater beneath agricultural and urban lands (Figure $4 \mathrm{a}$ ) and in major aquifers irrespective of overlying land use (Figure 4b). Areas that rank among the highest $25 \%$ of median concentration of nitrate in groundwater beneath land-use study areas (i.e., have median concentration of nitrate greater than $5 \mathrm{mg} / \mathrm{L}$ ) cluster in the mid-Atlantic and western areas of the Nation (Figure 4a). Contamination patterns of shallow groundwater reflect differences in nitrogen loading, land use, soil and aquifer permeability, irrigation practices, and other factors.

Figure4a also shows regional patterns of nitrogen loading by inorganic fertilizer, animal manure, and atmospheric deposition, compiled at the county level for mapping purposes. Most of the high groundwater nitrate values coincide with areas of high nitrogen loading, and the most extensive areas of high nitrogen loading are in the Midwest. These county data differ from loadings apportioned by specific land uses and compiled within $500 \mathrm{~m}$ of sampled wells. The latter data, discussed in the next section, were used in direct comparisons of nitrogen loading with nitrate concentration in groundwater beneath agricultural land.

Median concentrations of nitratein groundwater samples from major aquifers generally are less than the nitrate $M C L$ of $10 \mathrm{mg} / \mathrm{L}$ as N (Figure 4b). In 18 of 33 major aquifers sampled by NAWQA, no ground water samples exceed the nitrate MCL. The low rate of exceedances reflects generally greater depth to water and greater sampling depth within the saturated zone of these aquifers. Nitrate poses a health concern, however, in some major aquifers. For example, four major aquifers have more than $15 \%$ of groundwater samples with nitrate concentration exceeding the MCL (Figure 4b). The 


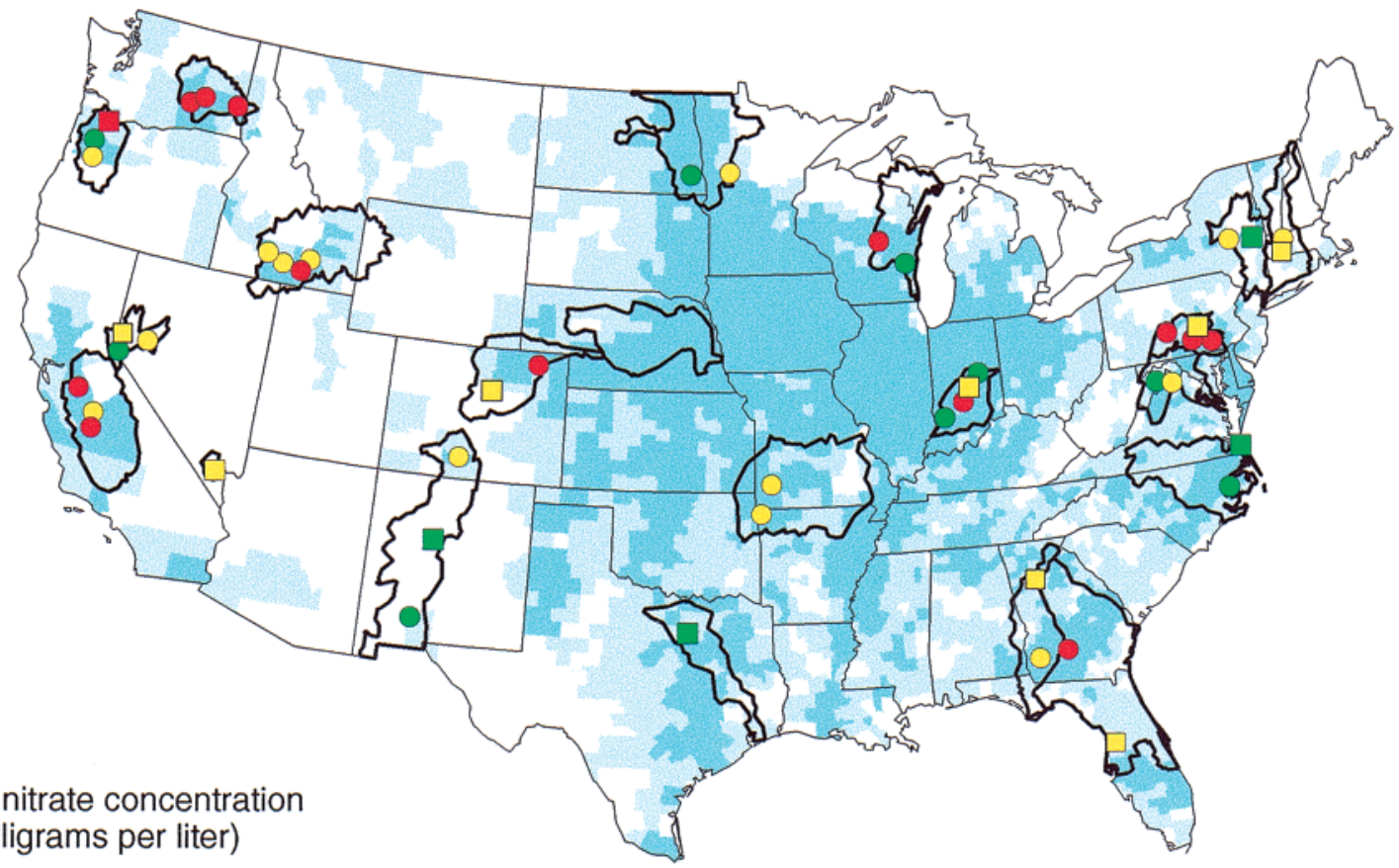

Median nitrate concentration (milligrams per liter)

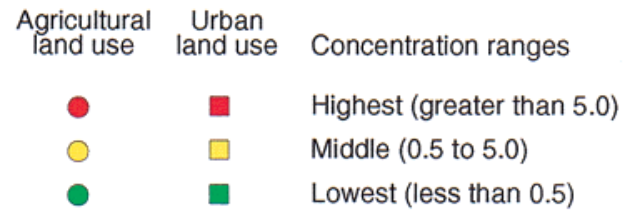

Average annual total nitrogen input by county for 1991-94 (kilograms per hectare)

Highest (equal to or greater than 28)

Middle (7 to 28 )

Lowest (less than 7)

$4 b$

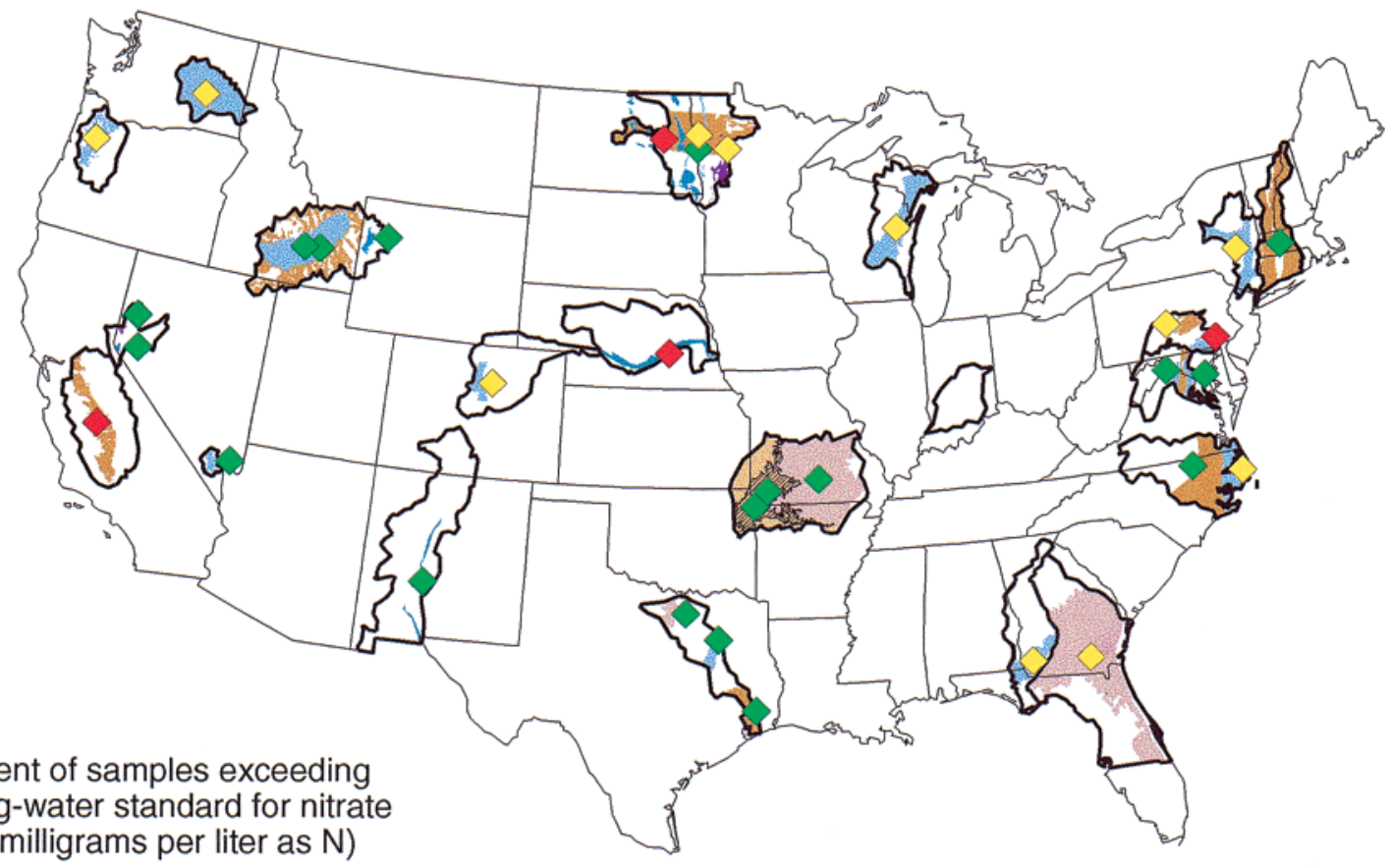

Percent of samples exceeding drinking-water standard for nitrate

(10 milligrams per liter as $\mathrm{N}$ )

Greater than 15

$\diamond$ Less than 15 (but at least 1 sample)

No samples exceed standard

Pattern and color shades indicate extent of the major aquifers studied.

FIGURE 4. (a) Median nitrate concentration in shallow groundwaters sampled by the NAW QA Program during 1992-1995. (b) Percent of samples exceeding the nitrate maximum contaminant level (10 $\mathrm{mg} / \mathrm{L}$ as $\mathrm{N})$ in major aquifers sampled by the NAW QA Program during $1992-1995$. 


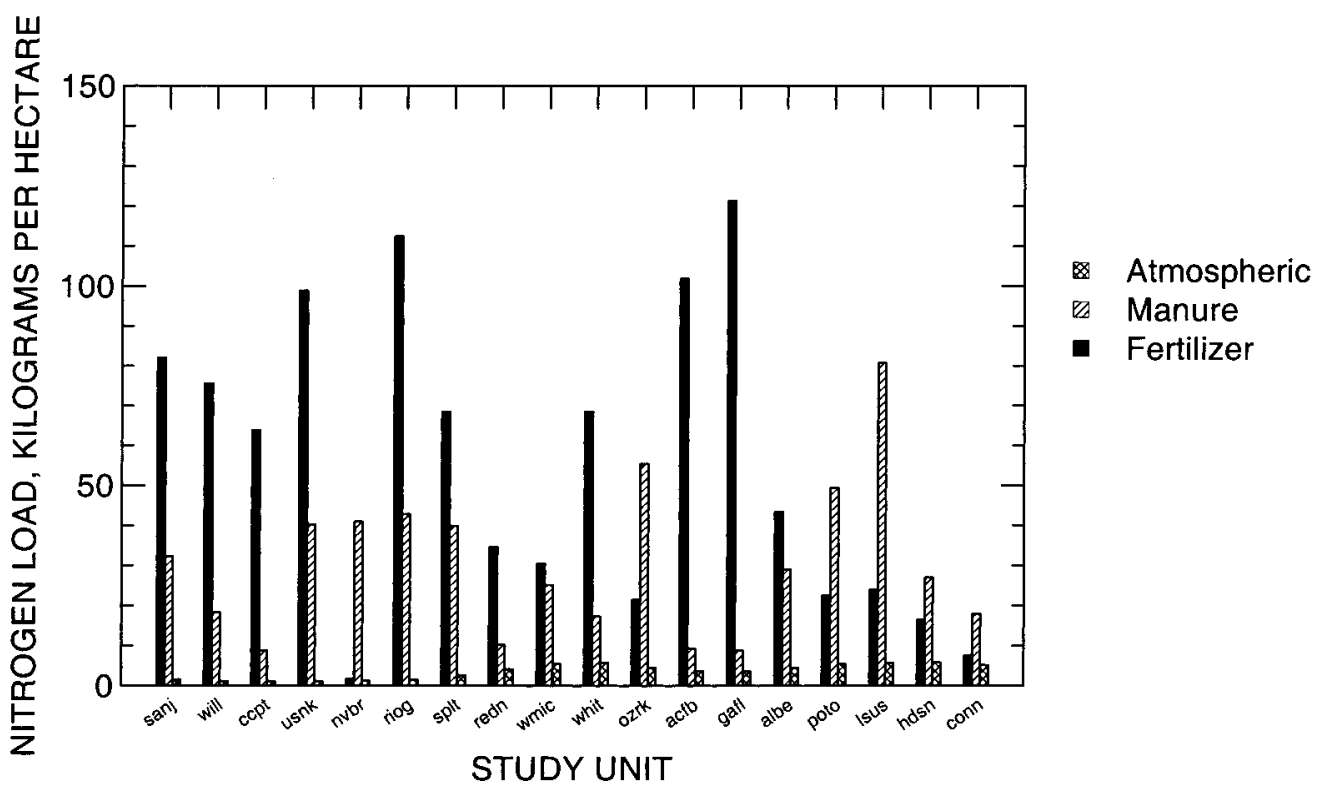

FIGURE 5. Average nitrogen load to agricultural lands within NAWQA study units during 1991-1993. (See Table 1 for definitions of study unit abbreviations.)

high exceedance percentages are associated with hydrogeologically susceptible aquifers under predominantly agricultural land use. The White River Basin did not conduct a major aquifer study, so these data are not available for southern Indiana (Figure 4b).

Relation of Nitrate Concentration in Shallow Groundwater to Explanatory Variables. Data for land-use studies indicate differences in nitrogen loading, climate, land use, soil drainage characteristic, aquifer vulnerability, irrigation practices, and geochemical conditions within aquifers. Contaminant behavior in groundwater systems is highly complex, and these and other factors interact to influence nitrate occurrence and distribution. As a result, nitrate behavior in response to any single factor is variable. The following discussion focuses on nitrate data from land-use studies, which are designed to sample recently recharged groundwater.

Nitrogen Loading. Averagenitrogen loading in agricultural lands was compiled by source for each NAWQA study unit to evaluate regional contributions by fertilizer, manure, and atmospheric deposition. Nitrogen loading from fertilizer and manure exceeds that by atmospheric deposition in all study units (Figure 5). Nitrogen loading from atmospheric deposition is greater in the eastern United States than in the western United States. Fertilizer loading generally is greater than manure loading, except in the Nevada Basin and Range and Ozark Plateaus and in study units in the mid-Atlantic and northeastern United States.

Median nitrate concentration in shallow groundwater beneath agricultural land was directly compared with median nitrogen loading from commercial fertilizer, animal manure, and atmospheric deposition (Figure 6). Nitrogen loading was estimated for a 500-m radius, circular area surrounding each well, and from these areas median loadings were calculated for each agricultural land-use study. The scatter in Figure 6 indicates that nitrate concentration in groundwater is influenced not only by nitrogen loading but by other factors as well. Agricultural lands with low median nitrogen loading (less than $65 \mathrm{~kg} / \mathrm{ha}$ ) but high nitrate concentration in groundwater ( $4 \mathrm{mg} / \mathrm{L}$ or more) general ly are associated with fractured rock or well-drained, coarse-textured soils that facilitate nitrate leaching to groundwater. These studies are indicated by the shaded area labeled "low load, high concentration" in Figure 6. Examplesincludecarbonate rocks

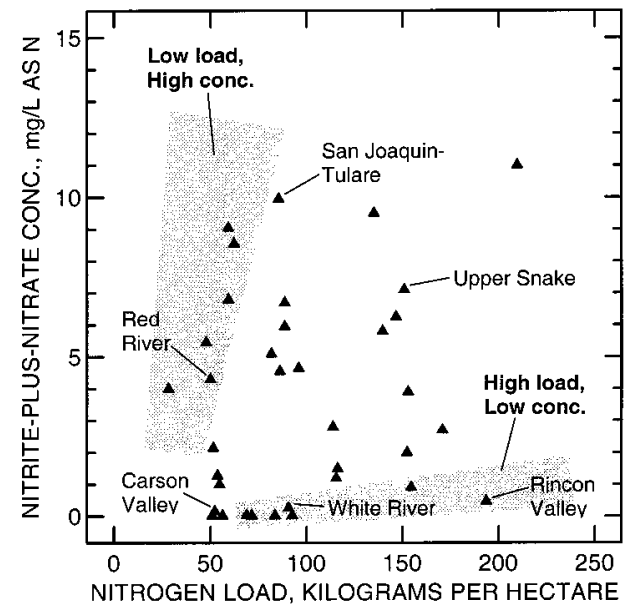

FIGURE 6. Relation betw een median nitrogen loading from fertilizer, manure, and atmospheric deposition in agricultural land-use study areas and median nitrate concentration in groundwater.

in the Lower Susquehanna Basin, southeastern Pennsylvania; sand and gravel deposits in the Western Lake Michigan Drainages, central Wisconsin; irrigated row crops over basalt and well-drained deposits in the Central Columbia Plateau, eastern Washington; and stratified glacial outwash and sedimentsin theConnecticut, Housatonic, and Thames River Basins in New England and in the Red River of the North Basin, northwestern Minnesota. For example, nitrate concentration in groundwaters of the Red River of the North Basin is highest in glacial outwash aquifers beneath agricultural lands. Although median nitrogen loading within 500 m of wells in these areas is less than $50 \mathrm{~kg} / \mathrm{ha}$, median nitrate concentration in groundwater is $4.3 \mathrm{mg} / \mathrm{L}$ (Figure 6), more than twice the background level of $2 \mathrm{mg} / \mathrm{L}$. The combination of irrigation, sandy soils, and conditions unfavorable to denitrification increases nitrate concentration in shallow groundwater in these areas (31).

In contrast, nitrate concentration in areas with moderate to high nitrogen loading (greater than $65 \mathrm{~kg} / \mathrm{ha}$ ) but low nitrate concentration in shallow groundwater (less than 1 $\mathrm{mg} / \mathrm{L}$ ) barely increases in response to nitrogen loading (Figure 6). These studies are indicated by the shaded area labeled "high load, low concentration" in Figure 6. These areas 
generally are underlain by unfractured, consolidated rock (sandstone or crystalline bedrock) or by fine-textured soils, which impede downward migration of water and chemicals. Examples include clay-rich glacial tills in the White River Basin, Indiana, and in the Western LakeM ichigan Drainages, and poorly drained areas of the Willamette Basin, northwestern Oregon.

Some areas with high nitrogen loading have low median nitrate concentration because of climatic factors. The Rincon Valley of southern New Mexico has a median nitrogen loading approaching $200 \mathrm{~kg} / \mathrm{ha}$, yet shallow groundwater in the area has a median nitrate concentration of only $0.48 \mathrm{mg} / \mathrm{L}$ (Figure 6). Average annual precipitation is less than $20 \mathrm{~cm}$ in the southern part of the Rio Grande Valley, where the Rincon Valley is located, and annual potential evaporation may exceed $1000 \%$ of annual precipitation (32). In contrast, annual precipitation in mountainous areas of the northern part of the Rio Grande Valley can exceed $120 \mathrm{~cm}$. Nitrate leaching patterns in the Rio Grande Valley vary considerably. The groundwater recharge rate (a factor in leaching) is affected by variations in "soil type, texture, permeability, precipitation, and biological/geochemical processes in the unsaturated zone" (32).

Elsewhere, high nitrate concentration in shallow groundwater generally is associated with high nitrogen loading. For example, median nitrate concentration in groundwater samples from the Minidoka Irrigation District in the Upper Snake River Basin, southeastern Idaho, is $7.1 \mathrm{mg} / \mathrm{L}$ (Figure 6). The area receives high nitrogen loading from fertilizer (151 kg/ha) and has well-drained soils and a shallow depth to groundwater (33).

Land Use. Nitrogen loading is related to land use. For example, shallow groundwater in almond orchard areas of the San Joaquin-Tulare Basins, central California, has a median nitrate concentration of $10 \mathrm{mg} / \mathrm{L}$. Almost the entire floor of the San Joaquin Valley is used for agricultural land (34). Median percent agricultural land within $500 \mathrm{~m}$ of sampled wells in the almond orchard area is nearly $100 \%$, and median nitrogen loading from inorganic fertilizers is moderately high at $85 \mathrm{~kg} / \mathrm{ha}$ (Figure 6).

Land usealone, however, can bea poor predictor of nitrate concentration in shallow groundwater. Some predominantly agricultural areas have low nitrogen loading and low nitrate concentration in groundwater. Shallow groundwater in the Carson Valley of western Nevada has a median nitrate concentration of only $0.16 \mathrm{mg} / \mathrm{L}$. Although the area is $94 \%$ agricultural land, nitrogen fertilizer loading around sampled wells is low (52 kg/ha) (Figure 6). Nitrogen loading from fertilizer and manure in western Nevada is significantly less than in the upper midwestern United States (35). Selected areas in western Nevada are planted in alfalfa, a legume that fixes atmospheric nitrogen. Additional nitrogen fertilizer is not needed after this crop is established.

Nitrate concentration in shallow groundwater beneath urban lands generally increases with increasing population density (Figure 7). Shallow groundwater in urban areas of the Willamette Basin near Portland, OR, has a median nitrate concentration of $5.4 \mathrm{mg} / \mathrm{L}$. In 1990, about 1.2 million people lived in Portland, the state's largest metropolitan area (36). The median population density within $500 \mathrm{~m}$ of sampled wells in the Portland area is 2300 people $/ \mathrm{km}^{2}$ (Figure 7). In contrast, shallow groundwater in urban areas of the Hudson River Basin near Albany, NY, has a median nitrate concentration of only $0.39 \mathrm{mg} / \mathrm{L}$, and themedian population density near sampled wells is only 380 people/ $\mathrm{km}^{2}$. Both studies are in areas with greater than $60 \%$ residential land use as defined by updated Anderson II data compiled for land-use study areas.

Soil DrainageCharacteristic. Soil drainage characteristic influences nitrate concentration in shallow ground water. The

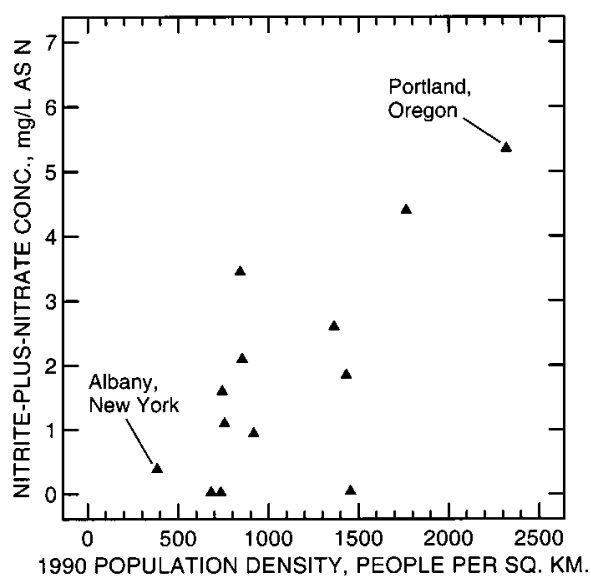

FIGURE 7. Relation between median population density in urban land-use study areas and median nitrate concentration in groundwater.

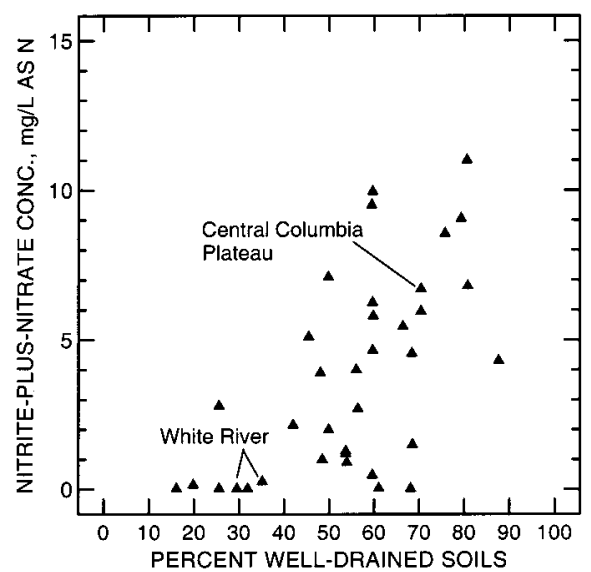

FIGURE 8. Relation between percent well-drained soils in agricultural land-use study areas and median nitrate concentration in groundw ater.

percent area of well-drained soils (soil hydrologic groups A and B in STATSGO) in agricultural land-use studies was compiled in a GIS and compared with median nitrate concentration in groundwater. As the percentage of welldrained soils increases, median nitrate concentration generally increases (Figure 8). Well-drained soils generally are coarse-grained and can easily transmit water and nitrate to groundwater. In contrast, poorly drained soils commonly are fine-grained and transmit water and nitrate at a slower rate than well-drained soils. Poorly drained soils also are anaerobic, which promotes conversion of nitrate to nitrogen gas and limits conversion of ammonia to nitrate (37).

Data for specific areas show the interaction between soil drainage characteristic and nitrogen loading. Shallow groundwater beneath agricultural lands (potatoes and corn) of the Central Columbia Plateau in southeastern Washington State has a median nitrate concentration of $6.7 \mathrm{mg} / \mathrm{L}$, and $70 \%$ of soils in the study area are classified as well-drained (Figure 8). High rates of nitrogen fertilizer application and extensive irrigation contribute to high nitrate concentration in groundwaters of the Central Columbia Plateau (38). Nitrateleaching in the area is enhanced because soils generally are welldrained, permeable, and underlain by unconsolidated sand and gravel (37). Extensiveirrigation in the area has increased the groundwater recharge rate, which helps move nitrate through the unsaturated zone.

Poorly drained soils can reduce the risk of groundwater contamination, even in areas with moderatenitrogen loading. Although agricultural lands in glacial lowlands of the White 
River Basin in southern Indiana receive $91 \mathrm{~kg} / \mathrm{ha}$ of nitrogen within $500 \mathrm{~m}$ of sampled wells, shallow groundwater in the area has a median nitrate concentration of only $0.27 \mathrm{mg} / \mathrm{L}$. Only $35 \%$ of soils in the area are classified as well-drained (Figure 8). Clay-rich deposits in the glacial lowlands protect aquifers from nitrate contamination (39). Additionally, shallow groundwater beneath agricultural land in a till-plain region of central Indiana has a median nitrate concentration of less than $0.05 \mathrm{mg} / \mathrm{L}$, even though the area receives 84 $\mathrm{kg} / \mathrm{ha}$ of nitrogen within $500 \mathrm{~m}$ of sampled wells. Thirty percent of soils in thearea are classified as well-drained. The poorly drained soils restrict downward movement of water and nitrate to the water table, and agricultural tile drains in the area intercept and divert soil water to streams before it reaches the aquifer. Nitrogen loading in the area is more likely to affect nearby streams than groundwater.

Irrigation. Irrigation practices can influence nitrate concentration in shallow groundwater. Groundwater beneath poorly drained agricultural lands in the Willamette Basin, northwestern Oregon, has median nitrate concentrations ranging from less than 0.05 to $2.80 \mathrm{mg} / \mathrm{L}$. The lower value represents nonirrigated agriculture and the higher value represents irrigated agriculture. Compared with nonirrigated crops, nitrogen application rates generally are greater on irrigated land (36), and irrigation increases groundwater recharge and subsequent leaching of nitrate.

Biogeochemical Transformations. Oxidation-reduction potential and related biogeochemical transformations influence nitrate concentration in groundwater. In carbon-rich systems that lack oxygen, nitrate is reduced to nitrogen gas by a bacterially mediated process called denitrification (40). Shallow groundwater beneath agricultural land in the North Carolina-Virginia Coastal Plain has a median nitrate concentration of less than $0.05 \mathrm{mg} / \mathrm{L}$, even though the rate of nitrogen loading within $500 \mathrm{~m}$ of sampled wells is $72 \mathrm{~kg} / \mathrm{ha}$. Water and sediment in the area contain sufficient carbon for bacterial reduction of nitrate to nitrogen gas and other reduced nitrogen species (41). Groundwater in the area has a comparatively high median dissolved organic carbon concentration $(4.2 \mathrm{mg} / \mathrm{L})$, and the median dissolved oxygen content of $2.1 \mathrm{mg} / \mathrm{L}$ is comparatively low (42).

In other areas, aquifer conditions might preclude biologically mediated transformation of ammonium to nitrite and nitrate via nitrification. Shallow groundwater beneath agricultural land in the Valley and Ridge Province, Potomac River Basin, has a median nitrate concentration of less than $0.05 \mathrm{mg} / \mathrm{L}$. Land within $0.4 \mathrm{~km}$ of sampled wells in the area is $35 \%$ forested (43). Groundwater in the area contains comparatively high median concentrations of ammonium $(0.06 \mathrm{mg} / \mathrm{L})$, iron $(515 \mu \mathrm{g} / \mathrm{L})$, manganese $(135 \mu \mathrm{g} / \mathrm{L})$, and low median dissolved oxygen $(0.5 \mathrm{mg} / \mathrm{L})$, consistent with reducing conditions (42). Median dissolved organic carbon concentration is low $(0.4 \mathrm{mg} / \mathrm{L})$, significantly less than in groundwaters of the North Carolina-Virginia Coastal Plain. Groundwater conditions in the forested areas of the Valley and Ridge apparently are sufficiently reducing to inhibit biologically mediated transformation of ammonium to nitriteand nitrate.

High NitrateConcentration in Major Aquifers. The above examples pertain to shallow groundwater beneath agricultural or urban lands. Additionally, some major aquifers (sampled irrespective of overlying land use) are hydrogeologically susceptibleto chemicalsapplied at the land surface. Groundwater in the Platte Valley of central Nebraska has a median nitrate concentration of $5.8 \mathrm{mg} / \mathrm{L}$, and the nitrate MCL (10 mg/L as N) is exceeded in $36 \%$ of the samples. Shallow depth to groundwater (median of $1.7 \mathrm{~m}$ ), sandy soils, and intensely irrigated cropland dominated by corn production contribute to the high occurrence of nitrate in the area (44).
Water from a major aquifer in Piedmont crystalline areas of southeastern Pennsylvania has a median nitrate concentration of $6.6 \mathrm{mg} / \mathrm{L}$, and the nitrate $\mathrm{MCL}$ is exceeded in $31 \%$ of the samples. Although the median depth to groundwater is greater $(12.8 \mathrm{~m})$ than in the PlatteValley, the aquifer consists of fractured crystal line rocks that are susceptible to recharge of water and chemicals from the land surface (45). Overlying land use in the area consists of mixed forest and agriculture, and groundwater is nitrogen-rich near hilltops where the agricultural land is most dense.

\section{Acknowledgments}

We thank the many NAWQA personnel who collected the water quality data used in this investigation. We thank Kerie J. Hitt, Barbara C. Ruddy, and David M. Wolockfor analyzing data in geographic information systems. Also thanksto Joseph M. Fenelon, Robert J. Gilliom, Chester Zenone, and three anonymous reviewers for providing insightful reviews that substantially improved this paper.

\section{Literature Cited}

(1) Puckett, L. J. Environ. Sci. Technol. 1995, 29, 408-414.

(2) Solley, W. B.; Pierce, R. R.; Perlman, H. A. Estimated Use of Water in the United States in 1990; U.S. Geological Survey: Reston, VA, 1993; Circular 1081.

(3) Fan, A. M.; Steinberg, V. E. Regul. Toxicol. Pharmacol. 1996, 23, 35-43.

(4) U.S. Environmental Protection Agency. Drinking Water Regulations and Health Advisories; Office of Water: Washington, DC, 1995.

(5) Centers for Disease Control and Prevention. Morbidity and Mortality Weekly Rep. 1996, 45, 569-572.

(6) Ward, M. H.; Mark, S. D.; Cantor, K. P.; Weisenburger, D. D.; Correa-Villaseñor, A.; Zahm, S. H. Epidemiology 1996, 7, 465471.

(7) Mueller, D. K.; Helsel, D. R. Nutrients in the Nation's WatersToo Much of a Good Thing?; U.S. Geological Survey: Denver, CO, 1996; Circular 1136.

(8) U.S. Environmental Protection Agency. Quality Criteria for Water-1986; U.S. Environmental Protection Agency: Washington, DC, 1986; Report EPA 440/5-86-001.

(9) Gilliom, R. J.; Alley, W. M.; Gurtz, M. E. Design of the Nationa Water-QualityAssessment Program: Occurrenceand Distribution of Water-Quality Conditions; U.S. Geological Survey: Sacramento, CA, 1995; Circular 1112.

(10) Lapham, W. W.; Wilde, F. D.; Koterba, M. T. Ground-Water DataCollection Protocols and Procedures for the National WaterQuality Assessment Program: Selection, Installation, and Documentation of Wells, and Collection of Related Data; U.S. Geological Survey: Reston, VA, 1995; Open-File Report 95-398.

(11) Lapham, W. W.; Wilde, F. D.; Koterba, M. T. Guidelines and Standard Procedures for Studies of Ground-Water Quality: Selection and Installation of Wells, and Supporting Documentation; U.S. Geological Survey: Reston, VA, 1997; Water-Resources Investigations Report 96-4233.

(12) Scott, J. C. Computerized Stratified Random Site-Selection Approaches for Design of a Ground-Water-Quality Sampling Network; U.S. Geological Survey: Oklahoma City, OK, 1990; Water-Resources Investigations Report 90-4101.

(13) Koterba, M. T.; Wilde, F. D.; Lapham, W. W. Ground-Water DataCollection Protocols and Procedures for the National WaterQuality Assessment Program: Collection and Documentation of Water-Quality Samples and Related Data; U.S. Geological Survey: Reston, VA, 1995; Open-File Report 95-399.

(14) Fishman, M.J. Methods of Analysis by theU.S. Geological Survey National Water QualityLaboratory-Determination of Inorganic and Organic Constituents in Water and Fluvial Sediments; U.S. Geological Survey: Denver, CO, 1993; Open-File Report 93125.

(15) Patton, C. J.; Truitt, E. P. Methodsof AnalysisbytheU.S. Geological Survey National Water Quality Laboratory-Determination of Total Phosphorus by a Kjeldahl Digestion Method and an Automated Colorimetric Finish That Includes Dialysis; U.S. Geological Survey: Denver, CO, 1992; Open-File Report 92146.

(16) Kolpin, D. W.; Barbash, J. E.; Gilliom, R. J. Environ. Sci. Technol. 1998, 32, 558-566. 
(17) Kolpin, D. W.; Goolsby, D. A.; Thurman, E. M. J. Environ. Qual. 1995, 24, 1125-1132.

(18) Battaglin, W. A.; Goolsby, D. A. Spatial Data in Geographic Information System Format on Agricultural Chemical Use, Land Use, and Cropping Practicesin theU nited States; U.S. Geological Survey: Denver, CO, 1995; Water Resources Investigations Report 94-4176.

(19) National Atmospheric Deposition Program. National Atmospheric Deposition Program (NRSP-3)/National TrendsNetwork, 1997; NADP/ NTN Program Office, Illinois State Water Survey: Champaign, IL, 1997.

(20) Puckett, L. J.; Hitt, K. J.; Alexander, R. B. County-based estimates of nitrogen and phosphorus content of animal manure in the United Statesfor 1982, 1987, and 1992; Available on the Internet at <URL: http:// water.usgs.gov/lookup/getspatial?manure> .

(21) U.S. Bureau of theCensus. 1992 Census of Agriculture(CD ROM); The Bureau: Washington, DC, 1995.

(22) Soil Conservation Service. Agricultural WasteManagement Field Handbook; U.S. Government Printing Office: Washington, DC, 1992; Chapter 4.

(23) Puckett, L.J.; Cowdery, T. K.; Lorenz, D. L.; Stoner, J. D. J. Environ. Qual. 1999, 28, 2015-2025

(24) Anderson, J. R.; Hardy, E. E.; Roach, J. T.; Witmer, R. E. A Land Use and Land Cover Classification System for Use with Remote Sensor Data; U.S. Geological Survey: Washington, DC, 1976; Professional Paper 964.

(25) Hitt, K. J. Refining 1970's Land-Use Data with 1990 Population Data to IndicateNew Residential Development; U.S. Geological Survey: Reston, VA, 1994; Water-Resources Investigations Report 94-4250.

(26) Soil Conservation Service. State Soil Geographic (STATSGO) Data Base for the United States and Puerto Rico (CD ROM); U.S. Department of Agriculture, Soil Conservation Service: Ft. Worth, TX, 1994. Available on the Internet at <URL: http:// www.ftw.nrcs.usda.gov/stat_data.html > .

(27) Speiran, G. K. Geohydrology and Geochemistry near Coastal Ground-Water-Discharge Areas of the Eastern Shore, Virginia; U.S. Geological Survey: Richmond, VA, 1996; Water-Supply Paper 2479.

(28) Hem, J. D. Study and Interpretation of the Chemical Characteristics of Natural Water; U.S. Geological Survey: Reston, VA, 1989; Water-Supply Paper 2254.

(29) Porter, K. S. Ground Water 1980, 18, 617-625.

(30) Nolan, B. T.; Ruddy, B. C.; Hitt, K. J.; Helsel, D. R. Environ. Sci. Technol. 1997, 31, 2229-2236.

(31) Stoner, J. D.; Lorenz, D. L.; Goldstein, R. M.; Brigham, M. E.; Cowdery, T.K. Water Quality in theRed River of theNorth Basin, Minnesota, North Dakota, and South Dakota, 1992-95; U.S. Geological Survey: Mounds View, MN, 1998; Circular 1169.

(32) Levings, G. W.; Healy, D. F.; Richey, S. F.; Carter, L. F. Water Quality in the Rio Grande Valley, Colorado, New Mexico, and Texas, 1992-95; U.S. Geological Survey: Albuquerque, NM, 1998; Circular 1162.
(33) Clark, G. M.; Maret, T. R.; Rupert, M. G.; Maupin, M. A.; Low, W. H.; Ott, D. S. Water Quality in the Upper Snake River Basin, Idaho and Wyoming, 1992-95; U.S. Geological Survey: Boise, ID, 1998; Circular 1160.

(34) Dubrovski, N. M.; Kratzer, C. R.; Brown, L. R.; Gronberg, J. M.; Burow, K. R. Water Quality in the San Joaquin-Tulare Basins, California, 1992-95; U.S. Geological Survey: Sacramento, CA, 1998; Circular 1159.

(35) Bevins, H. E.; Lico, M. S.; Lawrence, S. J. Water Quality in the Las Vegas Valley Area and the Carson and TruckeeRiver Basins, Nevada and California, 1992-96; U.S. Geological Survey: Carson City, NV, 1998; Circular 1170.

(36) Wentz, D. A.; Bonn, B. A.; Carpenter, K. D.; Hinkle, S. R.; Janet, M. L.; Rinella, F. A.; Uhrich, M. A.; Waite, I. R.; Laenen, A.; Bencala, K. E. Water Quality in the Willamette Basin, Oregon, 1991-95; U.S. Geological Survey: Portland, OR, 1998; Circular 1161.

(37) Mueller, D. K.; Hamilton, P. A.; Helsel, D. R.; Hitt, K. J.; Ruddy, B. C. Nutrientsin Ground Water and SurfaceWater of theU nited States-an Analysis of Data through 1992; U.S. Geological Survey: Denver, CO, 1995; Water-Resources Investigations Report 95-4031.

(38) Williamson, A. K.; Munn, M. D.; Ryker, S. J.; Wagner, R. J.; Ebbert, J. C.; Vanderpool, A. M. Water Quality in the Central Columbia Plateau, Washington and Idaho, 1992-95; U.S. Geological Survey: Tacoma, WA, 1998; Circular 1144.

(39) Fenelon, J. M. Water Quality in theWhiteRiver Basin, Indiana, 1992-96; U.S. Geological Survey: Indianapolis, IN, 1998; Circular 1150

(40) Korom, S. F. Water Resour. Res. 1992, 28, 1657-1668.

(41) Spruill, T. B.; Harned, D. A.; Ruhl, P. M.; Eimers, J. L.; McMahon, G.; Smith, K. E.; Galeone, D. R.; Woodside, M. D. Water Quality in the Albemarle-Pamlico Drainage Basin, North Carolina and Virginia, 1992-95; U.S. Geological Survey: Raleigh, NC, 1998; Circular 1157.

(42) Nolan, B. T. J. Environ. Qual. 1999, 28, 1518-1527.

(43) Ator, S. W.; Denis, J. M. Relation of Nitrogen and Phosphorus in Ground Water to Land Use in Four Subunits of the Potomac River Basin; U.S. Geological Survey: Baltimore, MD, 1997; WaterResources Investigations Report 96-4268.

(44) Frenzel, S. A.; Swanson, R. B.; Huntzinger, T. L.: Stamer, J. K. Emmons, P. J.; Zelt, R. B. Water Quality in theCentral Nebraska Basins, Nebraska, 1992-95; U.S. Geological Survey: Lincoln, NE, 1998; Circular 1163.

(45) Lindsey, B. D.; Breen, K. J.; Bilger, M. D.; Brightbill, R. A. Water Quality in the Lower Susquehanna River Basin, Pennsylvania and Maryland, 1992-95; U.S. Geological Survey: Lemoyne, PA, 1998; Circular 1168.

Received for review July 7, 1999. Revised manuscript recei ved December 2, 1999. Accepted December 29, 1999.

ES9907663 